九州大学学術情報リポジトリ

Kyushu University Institutional Repository

\title{
An Improved Method of Crystallization of Beef Liver Catalase
}

Shi rakawa, Masaharu

Laboratory of Biochemistry, Faculty of Agriculture, Kyushu University

https://doi.org/10.5109/22645

出版情報: 九州大学大学院農学研究院紀要. 10 (1)，pp.69-78，1951-10. Kyushu University バージョン：

権利関係 : 
Journal of the Faculty of Agriculture, Kyūshū University, Vol. 10, No. 1

October 30, 1951

\section{AN IMPROVED METHOD OF CRYSTAILLIZATION OF BEEF LIVER CATALASE}

\section{Masaharu SHIRAKaWA}

- On the way of purification of beef liver arginase, Kitagawa and author" obtained a crystalline protein and ascertained it to be identical with the crystalline catalase which had been first isolated by Sumner and Dounce ${ }^{2)}$ in 1937. In order to isolate the crystalline catalase, Sumner employed fractional precipitation by dioxane. An attempt to substitute acetone for dioxane was unsuccessful in those days. Dounce ${ }^{3)}$ reported in 1942 an acetone method which was almost identical in the principle with their original method.

Table 1. Crystalline catalase from various sources.

\begin{tabular}{|c|c|c|c|}
\hline Source & Isolated by & Year & Kat. f. \\
\hline Beef liver. & Sumner, Dounce ${ }^{2}$ ) & 1937 & 26,000 \\
\hline Beef liver & Kitagawa, Shirakawa" & 1941 & 32,000 \\
\hline Beef liver & Dounce $^{3 y}$ & 1942 & 35,000 \\
\hline Beef erythrocyte & Laskowski, Sumner & 1941 & 48,000 \\
\hline Horse liver & Agner ${ }^{n}$ & 1938 & 62,000 (amorph.) \\
\hline Horse liver & Dounce, Frampton') & 1939 & 50,000 to 55,000 \\
\hline ITorse liver & Anger ${ }^{7}$ & 1942 & 60,000 \\
\hline Horse erythrocyte & Anger ${ }^{8)}$ & 1941 & 65,000 (amorph.) \\
\hline Horse erythrocyte & Bonnichsen ${ }^{9}$ & 1947 & 65,000 \\
\hline Horse kidney & Bonnichsen ${ }^{10)}$ & 1948 & \\
\hline Guinea pig liver & Bonnichsen ${ }^{10)}$ & 1948 & \\
\hline Lamb liver & Dounce $^{3 \prime}$ & 1942 & \\
\hline Human liver & Bonnichsen ${ }^{10}$ ) & 1948 & \\
\hline Human erythrocyte & Bonnichsen ${ }^{10}$ ) & 1948 & 50,000 \\
\hline Human erythrocyte & Herbert, Prinsent ${ }^{111}$ & 1948 & \\
\hline $\begin{array}{l}\text { Bacteria } \\
\text { (Micrococcus } \\
\quad \text { lysorleikticus) }\end{array}$ & Herbert, Prinsent ${ }^{12}$ ) & 1948 & \\
\hline
\end{tabular}


Our method of crystallization of beef liver catalase, involving precipitation with acetone, heat treatment and salting out, was much improved there-after by further investigations.

At the stage of crystallization in the procedure, the precipitate obtained by salting out was dissolved in a small amount of water and soon after crystallization occurred. The fact in this case that the catalase crystallizes out from the same solution in which it once dissolved, is of much interest concerning the problem whether the crystalline catalase is of the same nature as in animal tissues or not. The change of the solubility of catalase at the stage. of crystallization should be considered as to suggest an accidental change of chemical properties, and therefore the crystalline catalase might be of a different nature from the enzyme in the native state except the catalytic character.

The catalase capability of our preparations, in term of "Kat. f.", amounted to about 32,000 , which was almost equal to that of Sumner's preparations, but much smaller than the value by Agner and Bonnichsen (Table 1). Attempts to increase "Kat. f." of preparations by means of recrystallization were in vain. Although many investigators ascribed the difference of catalase capability between horse and beef liver to the different hematin content, it was recently made clear that the crystalline catalase from beef liver contained almost the same amount of hematin iron as that from horse liver. ${ }^{13)}$ It is very important and interesting that catalase preparations have different capabilities according to their sources.

Catalase is generally supposed to be one of desmo-enzymes, which are bound to tissue cells. Bonnichsen ${ }^{10)}$ recognized recently that there was no essential difference immunologically between blood and liver catalases, and assumed that the source of liver catalase might be blood erythrocytes. But when the liver homogenate was placed under autolytic conditions, the amount of extractive catalase increased to a certain extent (about 40 per cent). This means that a considerable amount of catalase exists in the state of desmo-enzyme bound to tissue cells in the liver. The catalase capability of autolysate amounts to $350-400$ units of "Kat. f.". On the assumption that the pure beef liver catalase has a capability of about 30,000 , there must be about 1.2 grams of catalase in a liter of the extract. Nevertheless, in fact, only 
0.1 gram of catalase was separated in the crystalline state by our method.

The solubility measurements are often useful for the confirmation of the purity of proteins and enzymes. Standing on the basis of the phase rule, the solubility test enables us to decide whether the solute is monodisperse in the solution or not. From the analysis of the solubility, curve of the crystalline catalase, it was conclusively decided that the catalytic activity was essentially an attribute of the crystalline protein, and further the purity of the crystals as a protein was confirmed.

\section{EXPERIMENTAL}

\section{Activity Measurement.}

For the determination of reaction velocity the following system was employed,

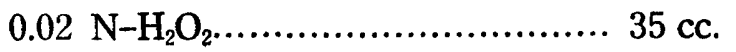

$$
\begin{aligned}
& \left.\begin{array}{l}
\mathrm{M} / 30 \text {-Phosphate buffer }(\mathrm{pH} 6.8) \ldots \ldots .10 \mathrm{cc} . \\
\text { Enzyme solution (diluted) ........... } 5 \mathrm{cc} .
\end{array}\right\} 0^{\circ} \mathrm{C} \text {. }
\end{aligned}
$$

$5 \mathrm{cc}$. enzyme solution (properly diluted) was added to the substrate mixture, from which $5 \mathrm{cc}$. was pipetted into $5 \mathrm{cc}$. of $2 \mathrm{~N}$-sulfuric acid, and from this moment reaction intervals were measured. Similar aliquots of the reaction mixture were pipetted into $2 \mathrm{~N}$ sulfuric acid at intervals, 2, 4, 6 and 10 minutes. The remaining quantity of hydrogen peroxide in each sample was determined by titration with $0.005 \mathrm{~N}$-permangante. Catalase activity was expressed with monomolecular velocity constant at 0 time which was obtained graphycally by extrapolation of $k$-values ${ }^{16)}$.

$$
k=\frac{1}{t_{\text {min. }}} \log _{10} \frac{a}{a-x}
$$

Euler and Josephson ${ }^{14)}$ had been defined the catalase capability, ".Kat. f.", as follows :

$$
\text { Kat. f. }=\frac{k}{D_{\text {grams }}} \text {. }
$$

Wherein $D$ implies the weight of dry matter in $5 \mathrm{cc}$. of the properly diluted enzyme solution. 


\section{Crystallization of Beef Liver Catalase.}

The improved method of crystallization and recrystallization of the beef liver catalase was summarized as follows:

Ground beef liver $(1 \mathrm{~kg}$.)

is treated with $1,000 \mathrm{cc}$. of distilled water and $5 \mathrm{cc}$. of toluene. The mixture is well agitated, allowed to stand over night in ice box, and then centrifuged (3,000 R.P.M., $40 \mathrm{~min}$.). Fat membrane separated on the surface is removed.

Supernatant solution (about $950 \mathrm{cc}$.).

$760 \mathrm{cc}$. of acetone is added slowly under cooling. After standing for 1 hour,

- the mixture is centrifuged (3,000 R.P.M., $30 \mathrm{~min}$.).

Precipitate is extracted with $300 \mathrm{cc}$. of water and insoluble matter is centrifuged off and $240 \mathrm{cc}$. of acetone is added to the solution under cooling. Centrifugation (3,000 R.P.M., $30 \mathrm{~min}$.).

Precipitate

is dissolved in $150 \mathrm{cc}$. of water and the insoluble matter is centrifuged off. $20.7 \mathrm{~g}$. of ammonium sulfate (recrystallized) is added slowly to the solution (about 0.25 saturation) and the precipitate formed is removed. $18.2 \mathrm{~g}$. of ammonium sulfate is added again to the solution and after standing for 30 min. under cooling, the mixture is centrifuged (3,000 R.P.M., $20 \mathrm{~min}$.).

Precipitate

is dissolved in $10 \mathrm{cc}$. of water and the insoluble matter is removed at once by centrifugation (4,000 R.P.M., $5 \mathrm{~min}$.). The solution is allowed to stand in the ice box over night. Crystallization occurs ordinally in $30 \mathrm{~min}$. and completes in one day. Centrifugation (4,500 R.P.M., $25 \mathrm{~min}$.).

Crude crystals (needles; Kat., 1,000 to 1,500)

is washed 3 times with a small amount of water by centrifugation to re. move ammonium sulfate and is suspended in $10 \mathrm{cc}$. of water. $0.1 \mathrm{~N}-\mathrm{NaOH}$ is added drop by drop in the suspension until the thryxotropy* almost completely disappears (under $\mathrm{pH} 7.5 \dagger$ ), and the insoluble amorphous proteins are centrifuged off.

Supernatant solution (about $10 \mathrm{cc}$.)

is titrated to $\mathrm{pH} 5.7$ with saturated solution of $\mathrm{KH}_{3} \mathrm{PO}_{4}$ and is allowed to stand in the ice box. In 30 minutes crystallization occurs and completes in 12 hours. Centrifugation.

Crystalline catalase (plates; Kat. f., 10,000 to 15,000 ; yield, 0.1 g.)

The catalase capability can be lifted to about 30,000 by two or three times recrystallization. The crude crystals were usually needle shaped, but the recrystallized one was plates (Figs. 1 and 2). It appears that catalase crystallizes in plates from its concentrated solution near the isoelectric point when the salt concentration is comparatively low, and in needles when the con-

* The suspension of crystalline catalase shows a beautiful and silky appearance, which had been characterized by Sumner and Dounce") as "thryxotropy". By this characteristic one is able to ensure easily occurrence and solution of crystals.

$\uparrow$ When stocked in ice box for weeks, crystals are often subjected to gradual denaturation and become insoluble at $\mathrm{pH} 7.5$. 
ditions are not optimum. When the needle crystalls were allowed to stand for a few weeks with its mother liquor, it yielded large and irregular shaped inactive crystals, which might be crystals of denatured catalase (Fig. 3).



Fig. 1. Crystalline Catalase (needles) $\times 250$.

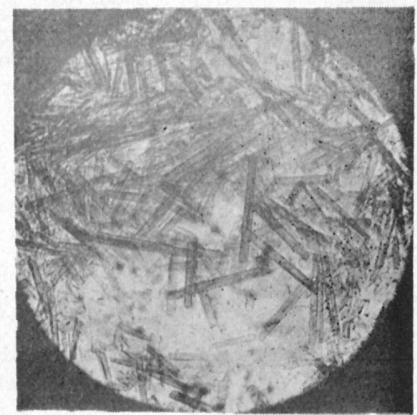

Fig. 2. Crystalline Catalase (plates) $\times 100$.

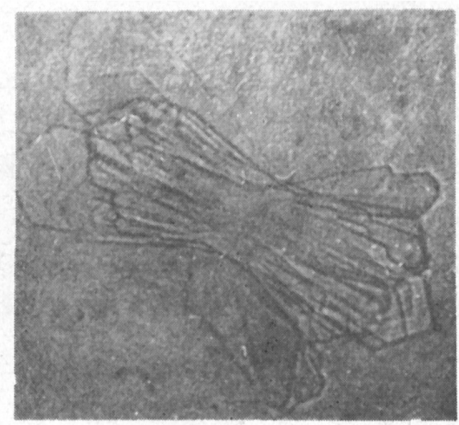

Fig. 3. Denatured Crystalline Catalase $\times 400$.

III. Autolysis of Beef Liver and Catalase Activity.

Attention was scarcely payed so far for autolysis in the purification of liver catalase. If catalase exists in the liver as a desmo-enzyme, it will be possible to increase the yield of crystalline catalase by a moderate autolysis of liver.

When ground beef liver was mixed with an equal portion of water and a small amount of toluene and then allowed to stand at $25^{\circ} \mathrm{C}$., the amount of extractive catalase gradually increased together with the amount of soluble amino nitrogen, showing a maximum value (about 40 per cent increasement). at 20 hours' autolysis. At the maximum point the acidity of liver homogenate 
reached to $\mathrm{pH} 5.3$ and soluble amino nitrogen increased by about 20 per cent of total nitrogen (Table 2).

Table 2. The effect of autolysis of beef liver on catalase activity.

\begin{tabular}{c|c|c|c|c}
\hline $\begin{array}{c}\text { Intervals } \\
\text { of } \\
\text { autolysis }\end{array}$ & $\mathrm{pH}$ & \multicolumn{2}{|c|}{ Amino nitrogen } & $\begin{array}{c}\text { Activity } \dagger \\
\text { cmm. O/ } / 3 \text { min. }\end{array}$ \\
\hline 0 & 6.45 & 1.09 & 7.5 & 92 \\
6 (hrs.) & 6.40 & 1.24 & 8.5 & 98 \\
12 & 6.02 & 1.75 & 12.0 & 119 \\
18 & 5.53 & 2.30 & 15.7 & 127 \\
24 & 5.20 & 3.06 & 21.0 & 128 \\
48 & 5.00 & 4.99 & 34.0 & 96 \\
\hline
\end{tabular}

* After van Slyke.

$\dagger$ Measured by manometric method.

Enzyme system: $\mathrm{M} / 15$-phosphate $(\mathrm{pH} 6.8) 3.00 \mathrm{cc}$.

0.1 M-hydrogen peroxide $0.50 \mathrm{cc}$. $30^{\circ} \mathrm{C}$.

Enzyme solution

$0.10 \mathrm{cc}$.

Unlike the case of the former method, the autolysis of liver homogenate yielded a clear reddish brown solution, which contained no colloidal suspensions. Hereby, the following manipulations of purification became considerably easy, but the yield of crystalline catalase decreased rather than by the usual method. To obtain crystalline catalase from the dialysate with better yield, the method was modified as follows:

Finely ground beef liver ( $1 \mathrm{~kg}$.)

is mixed with $1,000 \mathrm{cc}$. of water and $5 \mathrm{cc}$. of toluene, and the mixture is allowed to stand for 20 hours at $25^{\circ} \mathrm{C}$. Centrifugation.

Supernatant solution (about $950 \mathrm{cc}$; Kat. f., 370)

is treated with 0.8 volume of acetone as before. Centrifugation.

Precipitate (Kat. f., 790)

is extracted with $250 \mathrm{cc}$. of water and the insoluble matter is centrifuged off. The solution is treated again with 0.8 volume of acetone. Centrifugation.

Precipitate

is extracted with $100 \mathrm{cc}$. of water. 2 cc. of $0.1 \mathrm{M}$-phosphate buffer (pH 7.2) and $2 \mathrm{~g}$. of saliva are added to the solution. The mixture is allowed to stand for 10 hours at room temperature $\left(18^{\circ} \mathrm{C}\right.$.). A calculated amount of ammonium sulfate is added to bring the solution to 0.25 saturation. Centrifugation.

Supernatant solution

is brought to 0.45 saturation by addition of ammonium sulfate. Centrifugation. 


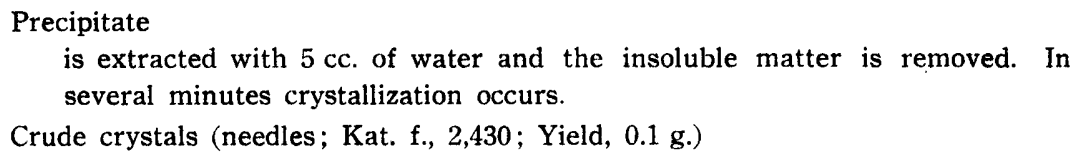

Although, in this example, the yield of catalase was better than by the former method, it appears to require skill to obtain crystals by this method. It happened sometimes that catalase did not crystallize owing to obscure causes. The conditions of each step should be investigated still further.

\section{Solubility Test.}

The measurement was performed according to the description of Northrop ${ }^{15}$. The thrice recrystallized catalase preparation (Kat. f., 32,100) was washed several times with water and further three times with $0.05 \mathrm{M}$-phosphate buffer ( $\mathrm{pH}$ 6.5) and then was suspended in $15 \mathrm{cc}$. of the same buffer. This original suspension was successively diluted with the buffer as many as $4,12,36,72$, 144 and 288 times. $10 \mathrm{cc}$. of each suspension was pipetted into the centrifuging tube of $2 \mathrm{~cm}$ inside diameter and $25 \mathrm{cc}$. capacity, and agitated for 15 minutes with rotating stick (500 R.P.M.) to achieve the solubility equilibrium. After one hours' standing the suspensions were centrifuged (5,000 R.P.M., $20 \mathrm{~min}$.) and then the catalase activity as well as the nitrogen content of the supernatant solutions were estimated by the usual method. All the operations were performed at room temperature. Considering the effect of temperature during centrifugation, four samples were centrifuged at the same time.

Table 3. Solubility measurements of the crystalline catalase

(Kat. f., 32,$100 ; \mathrm{pH} 6.5 ; 18^{\circ} \mathrm{C}$ ).

\begin{tabular}{c|c|c}
\hline $\begin{array}{c}\text { Dilution of the } \\
\text { suspension }\end{array}$ & $\begin{array}{c}\text { Activity } \\
k / \mathrm{cc} .\end{array}$ & $\begin{array}{c}\text { Nitrogen } \\
\mathrm{mg} / \mathrm{cc} .\end{array}$ \\
\hline 1 & 149 & 0.742 \\
4 & 146 & 0.728 \\
12 & 147 & 0.735 \\
36 & 115 & 0.588 \\
72 & 71 & 0.364 \\
144 & 36 & 0.182 \\
288 & 16 & 0.098 \\
\hline
\end{tabular}


Results obtained were summarized in Table 3 and the typical solubility curve of crystals of maximum purity were illustrated in Fig. 4. The fact that the activity curve is almost parallel to the nitrogen curve should imply the identity of the carrier of these two characters. In Table 4 and Fig. 5 results of solubility measurements about three kinds of crystals. with different purities were comparatively illustrated. These curves offer a further support to the conclusion above-mentioned.

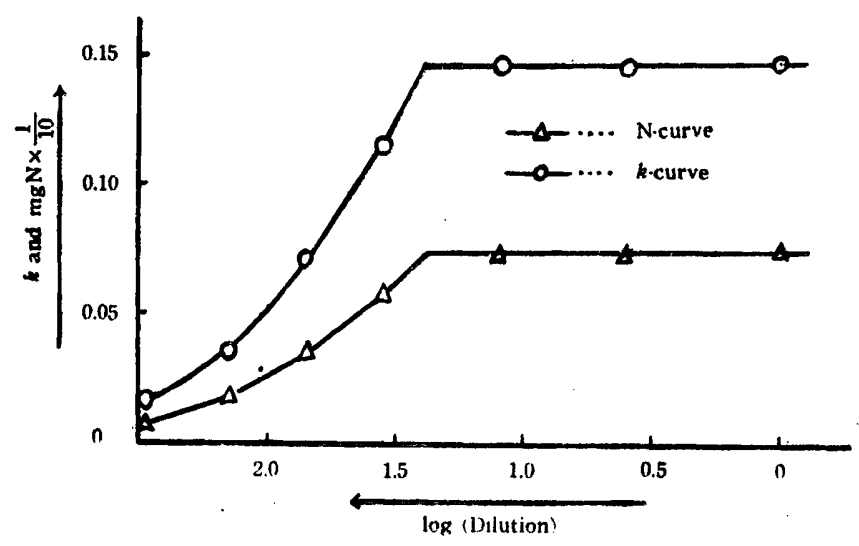

Fig. 4. The solubility curve of the crystalline catalase $\left(18^{\circ} \mathrm{C}, \mathrm{pH} 6.5\right)$.

Table 4. Solubility measurements of catalase preparations of various purities. $\left(15^{\circ} \mathrm{C}, \mathrm{pH} 6.5\right)$.

\begin{tabular}{|c|c|c|c|c|c|c|}
\hline \multirow{2}{*}{$\begin{array}{l}\text { Dilution } \\
\text { of the } \\
\text { suspension }\end{array}$} & \multicolumn{2}{|c|}{$\begin{array}{l}\text { Preparation I } \\
\text { (Kat. f., 1,230) }\end{array}$} & \multicolumn{2}{|c|}{$\begin{array}{l}\text { Preparation II } \\
\text { (Kat. f., 24,000) }\end{array}$} & \multicolumn{2}{|c|}{$\begin{array}{l}\text { Preparation III } \\
\text { (Kat. f., } 30,500 \text { ) }\end{array}$} \\
\hline & $k / \mathrm{cc}$ & $\mathrm{mg} . \mathrm{N} / \mathrm{cc}$ & $k / \mathrm{cc}$ & mg. N/cc. & $k / \mathrm{cc}$ & $\mathrm{mg} . \mathrm{N} / \mathrm{cc}$. \\
\hline 1 & 40.6 & 3.94 & 142.2 & - & 130.6 & - \\
\hline 4 & 37.2 & 3.41 & 136.4 & - & 128.0 & 0.714 \\
\hline 12 & 30.9 & 2.90 & 128.6 & - & 128.6 & - \\
\hline 36 & 15.1 & 1.93 & 117.8 & - & 92.2. & 0.539 \\
\hline 72 & 7.7 & 1.03 & 57.4 & - & 52.2 & - \\
\hline 144 & 4.0 & 0.52 & 30.2 & - & 25.4 & 0.146 \\
\hline 288 & - & - & - & - & 14.6 & - \\
\hline
\end{tabular}




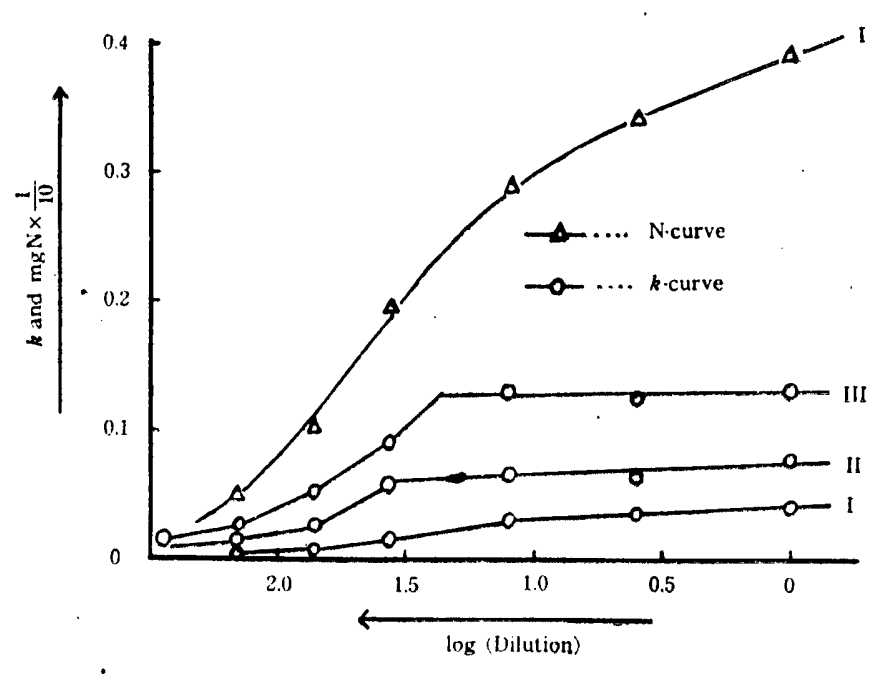

Fig. 5. Solubility curves of crystalline catalase preparations with different purities $\left(15^{\circ} \mathrm{C}, \mathrm{pH} 6.5\right)$.

\section{SUMMARY}

(1) An improved method of crystallization and recrystallization of beef liver catalase was described.

(2) When the liver was autolysed at $25^{\circ} \mathrm{C}$, the amount of extractive catalase increased by about 40 per cent during the first 20 hours, showing a maximum increasement.

(3) By some modifications of the technique, crystalline catalase was obtained from the autolysate with a better yield.

(4) By means of the solubility test, it was conclusively decided that the catalytic activity was essentially an attribute of the crystalline protein, and further the purity of the crystals as protein was confirmed.

The author is grateful to Professor Yasuyoshi Oshima for his continued help and advice. 


\section{BIBLIOGRAPHY}

1) M. Kitagawa and M. Shirakawa: J. Agric. Chem. Soc., Japan, 17, 794 (1941).

2) J. B. Sumner and A. L. Dounce: J. Biol. Chem., 121, 417 (1937).

3) A. L. Dounce: J. Biol. Chem., 143, 497 (1942).

4) M. Laslowski and J. B. Sumner: Science, 94, 615 (1941).

5) K. Agner: Biochem. J., 32, 1702 (1938).

6) A. L. Dounce and V. L. Framptom: Science, 89, 300 (1939).

7) K. Agner: Arch. Kemi. Minel. Geol., A 16 No. 6, 1 (1941).

8) K. Agner: Acta Physiol. Scand., 2, Suppl. VlII (1941).

9) R. Bonnichsen: Arch. Biochem., 12, 83 (1947).

10) R. Bonnichsen: Acta Chem. Scand., 2, 561 (1948).

11) D. Herbert and A. J. Prinsent: Biochem. J., 43, 203 (1948).

12) D. Herbert and A. J. Prinsent: Biochem. J., 43, 193 (1948).

13) M. Shirakawa: J. Agric. Chem. Soc., Japan, 23, 186 (1949).

14) H. v. Euler and K. Josephson: Ann., 452, 158 (1927).

15) J. H. Northrop: J. Gen. Physiol., 13, 763 (1930). 